\title{
PATHOMORPHOLOGICAL LESIONS AND DISTRIBUTION OF VIRAL ANTIGEN IN BIRDS INFECTED WITH THE PATHOGENIC STRAIN OF H5N1 AVIAN INFLUENZA VIRUS
}

\author{
VASKOVIĆ N*, ŠEKLER M*, VIDANOVIĆ $D^{*}$, POLAČEK V*, KUKOLJ V**, MATOVIĆ K* \\ and JOVANOVIĆ $M * *$ \\ *Veterinary Institute "Kraljevo", Kraljevo, Serbia \\ **University of Belgrade, Faculty of Veterinary Medicine, Serbia \\ (Received 29th May 2011)
}

The aim of this study was to determine pathomorphological lesions in the organs of birds infected with H5N1 avian influenza virus, presence and distribution of the viral antigen in tissue samples and the degree of their correlation. Examination was conducted on the carcasses of seven mute swans (Cygnus olor) and one domestic rooster (Gallus gallus domesticus). After necropsy, trachea, lungs, liver, spleen, pancreas, kidney and intestine tissues were sampled for histopathology and immunohistochemical examination. LSAB method and H5N1 avian influenza virus nucleoprotein polyclonal antibodies were used for detecting the viral antigen in the examined tissues.

The most frequent gross lesions were hemorrhages and necroses of the pancreas. Major histological lesions were multifocal necroses in the pancreas, liver and spleen, non purulent encephalitis, with neuronal dystrophy and neuronophagia. Viral nucleoprotein was immunohistochemically proven in the pancreas, brain, liver, lungs, and in one swan in the kidney. A high correlation between pathomorphological lesions and distribution of the viral antigen was determined.

Key words: brain, H5N1, immmunohistochemistry, pancreas, pathomorphological lesions, swan

\section{INTRODUCTION}

In February 2006, in the laboratory of the Veterinary Institute Kraljevo, Serbia, the presence of the highly pathogenic avian influenza virus, subtype H5N1, was confirmed in a swan carcass. At that moment, a large number of European countries, including our neighboring states, reported the occurence of this virus in wild birds and domestic poultry to the OIE. The public was focused on avian influenza, because of possible major economic losses, as well as possible threats to the health of the human population. During the following two months, a large number of wild aquatic birds and domestic poultry from all over Serbia were examined for the avian influenza virus. For most of birds, including swans, the 
cause of death was exhaustion, and probably lack of food, common for the weather conditions and migration patterns at that time, but also mechanical trauma, bacterial and fungal infections. The presence of avian influenza virus was confirmed in the carcasses of one domestic rooster and seven mute swans. According to available data literature, mortality caused by avian influenza was relatively rare in wild waterfowl, usually restricted to individual cases. Swans, as representatives of the order Anseriformes, together with wild geese and ducks, are marked as the main reservoir of the virus, in which the disease usually runs asymptomaticaly and the moratality is low (Hinshaw et al., 1986; Perkins and Swayne, 2002; Ellis et al., 2004). However, several recent studies (Ellis et al., 2004; Teifke et al., 2007; Brown et al., 2008), as well as reports of a relatively large number of dead swans in several European countries in which the avian influenza virus was isolated, testifies to the fact that the swans are one of the least resistant to the virus of all waterfowl birds of the order Anseriformes, and may represent a very important species for studying the epidemiology of avian influenza. Some autors even say that swans are not a biologically important vector of avian influeza, but rather "closing hosts" in its transmition (Nagy et al., 2007), and that they could be used, after complete clarification of disease pathogenesis and species susceptibility, as avian influenza indicators in wildlife (Teifke et al., 2007).

\section{MATERIALS AND METHODS}

\section{Gross examination}

Examination was done on the organs (brain, trachea, lungs, liver, spleen, pancreas, kidney and intestine) of seven mute swans (Cygnus olor) and one domestic rooster (Gallus gallus domesticus) in which the highly pathogenic avian influenza virus, subtype H5N1, was previously proven by virological methods, virus isolation in chicken embryos and molecular techniques. The carcasses of these birds were shipped to the Veterinary Institute Kraljevo laboratory from two locations in western and north - western Serbia.

\section{Histopathology}

After necropsy and gross examination, tissues of the brain, trachea, lungs, liver, spleen, pancreas, kidney and intestine were taken for pathohistological and immunohistochemical studies. Samples were fixed in 10\% buffered formalin for 48 hours, and after standard processing in an automated tissue processor were cast in paraffin blocks. Paraffin sections, $4-5 \mu \mathrm{m}$ thick, were stained with haematoxylin and eosin (HE).

\section{Immunohistochemistry}

The labeled streptavidin-biotin (LSAB) method was used for immunohistochemical staining (ChemMate, DAKO, Denmark). After dewaxing and rehydratation, antigen retrieval (citric buffer, $560 \mathrm{~W}, 21 \mathrm{~min}$ ) was done. Inhibition of endogenous peroxidase was obtained by treatment of sections in 3\% solution of hydrogen peroxide in methanol for 15 minutes. Sections were incubated with normal goat serum for $\mathbf{3 0}$ minutes at room temperature. In order to 
detect the avian influenza antigen, sections were incubated with a rabbit antinucleoprotein serum kindly provided by Dr. Jens P. Teifke (the Federal Research Institute for Animal Health, Greifswald-Insel Riems, Germany) (1:500 dilution in TBS). A biotynilated goat anti-rabbit immunoglobulin (ChemMate, DAKO, Denmark) was used as the secondary antibody. All sections were incubated with streptavidin-peroxidase complex (ChemMate, DAKO, Denmark) for 20 minutes at room temperature. Reaction was visualised by using diaminobenzidine tetrahydrochloride (Liquid DAB, DAKO, Denmark) or 3-amino9-ethylcarbazole (AEC, ChemMate, DAKO, Denmark) and counterstained with Mayer's haematoxylin. As a negative control, slides were incubated with PBS instead of primary antibodies.

\section{RESULTS}

\section{Gross examination}

The dominant findings were lesions in the pancreas, which were found in all birds, in the form of disseminated and patchy, demarcated hemorrhages and necrotic fields of irregular shapes, different sizes, from a few millimeters to one and a half centimeters in diameter (Fig. 1a). In two swans, petechiation of subcutaneous tissue and seroses of the sternum was present. Blood vessels of the brain and meninges were initiated (Fig. 1b). Lung congestion and edema were common findings. Subepicardial hemorrhages were found in two swans. In most cases, the liver and spleen were enlarged and congested, some of them with subcapsular hemorrhages and focal necroses. In two swans, kidneys were enlarged and congested. The mucoses of the small intestine and rectum were diffusely hyperemic, in some cases hemorrhages were present in the small intestine, rectal mucosa and cecal tonsils. In the rooster, cyanosis of the comb and distal parts of the legs were observed. Blood vessels of the brain and meninges were initiated. Tracheal mucose was diffusely hyperemic, a blood clot was present in the lumen. The lungs and the liver were congested. Hemorrhages and necroses of pancreas were observed. Hemorrhages were also observed on duodenal, rectal and proventricular mucoses.

\section{Histopathology}

Non-purulent encephalitis with perivascular accumulation of lymphocytes and plasmocytes was found in the cerebrum. Dystrophy, necroses of nerve cells and neuronophagia were also present. Lung congestion and edema were observed. In the liver, hemorrhages and focal areas of hepatocellular necrosis with mononuclear cells and heterophils, were found (Fig. 1c). Surrounding hepatocytes were swollen and infiltrated with mononuclears and heterophiles. A similar finding was noted in the spleen, where multifocal coagulative necrosis of lymphoid tissue was observed. In necrotic debris and surrounding tissue, lymphocytes, macrophages and heterophils were present. Karyorexis of lymphoid cells was observed. The predominant findings in the pancreas were also multifocal hemorrhages and necroses of exocrine acinar cells (Fig. 1d). Areas of coagulative necrosis were infiltrated with mononuclears and heterophils. 
These cells were also found in the surrounding tissue that showed signs of mild to moderate inflammation. In the small intestine, desquamation of surface epithelium was observed. Propria mucosae and submucosa were infiltrated with heterophils, which were also present in the exudate between the intestinal villi. Trachea and kidneys had no histological lesions.
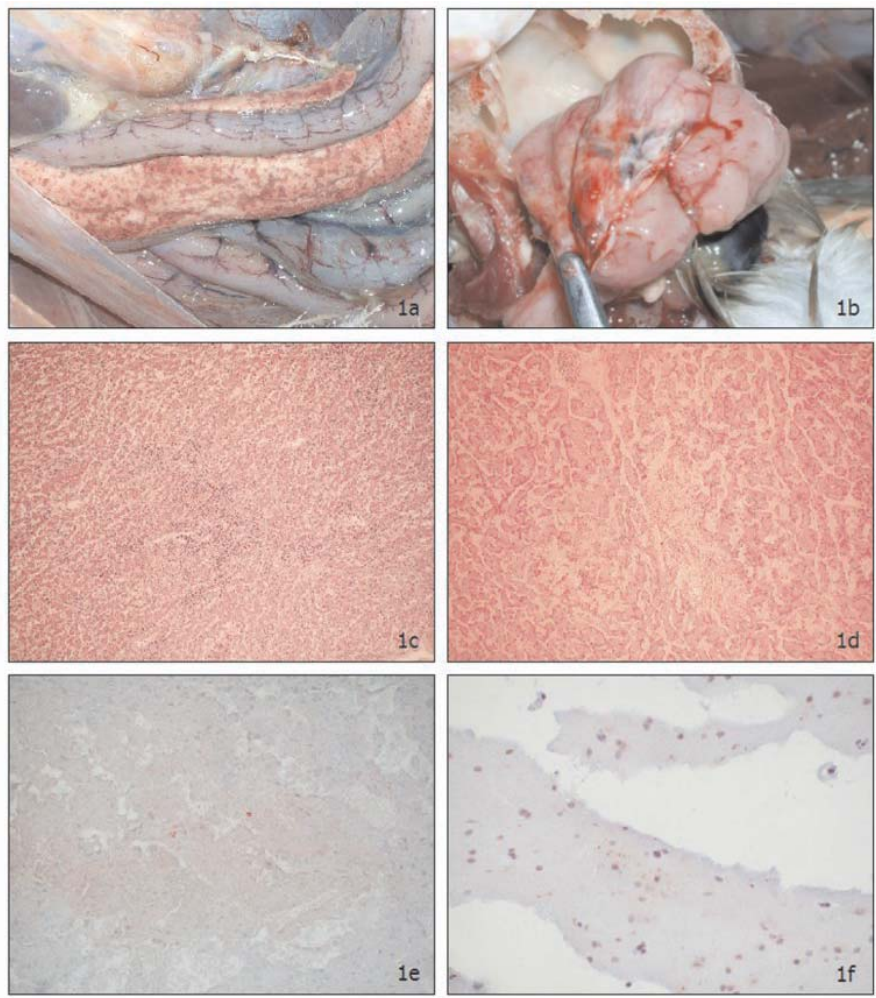

Figure 1. a) Pancreas; mute swan. Multifocal necrosis and hemorrhages. b) Brain; mute swan. Initiated blood vessels. c) Liver; mute swan. Necrosis, HE, x100. d) Pancreas; mute swan. Necrosis, HE, x100. e) Pancreas; mute swan. Against AIV nucleoprotein, LSAB, x400. f) Brain; mute swan. Against AIV nucleoprotein, LSAB, x400

\section{Immunohistochemistry}

The viral nucleoprotein was most frequently detected in tissues of the pancreas, brain and liver. In the pancreas, it was detected in all samples, in areas of necrosis, in necrotic debris, and in cytoplasm and nucleus of exocrine acinar cells (Fig. 1e). In the cerebrum, the viral antigen was observed in the cytoplasm and nucleus of neurons and glial cells (Fig. 1f). In the lungs, it was detected in the nucleus and cytoplasm of endothelial cells of blood vessels. Positive immunohistochemical signal was noted in the liver, in the necrotic areas, in nuclei 
and cytoplasm of hepatocytes, blood vessels endothelial cells and macrophages. In the spleen, it was also noted in the areas of necrosis, the nucleus and cytoplasm of mononuclear cells and blood vessels endothelial cells. In one sample, the viral antigen was detected in the cytoplasm and nucleus of tubular epithelial cells and blood vessels endothelium of the kidneys. In examined tissues of the trachea and small intestine, there was no positive immunohistochemical signal of the presence of avian influenza virus antigen.

Table 1. Major histological lesions and distribution of influenza virus antigen

\begin{tabular}{|l|l|c|l|}
\hline Organ & Histopathology & $\begin{array}{c}\text { IHC } \\
\text { positive }\end{array}$ & Cell types \\
\hline \hline Brain & $\begin{array}{l}\text { Non-purulent encephalitis, } \\
\text { neuronophagia }\end{array}$ & $1 / 1$ & Neurons, glial cells \\
\hline Trachea & No lesions & $0 / 8$ & No lesions \\
\hline Lung & Edema and congestion & $4 / 8$ & Vascular endothelium \\
\hline Liver & Multifocal necrosis & $5 / 8$ & Hepatocytes \\
\hline Spleen & Multifocal necrosis & $3 / 8$ & Lymphoid cells \\
\hline Pancreas & Multifocal necrosis & $8 / 8$ & Exocrine acinar cells \\
\hline Small intestine & Catarrhal enteritis & $0 / 8$ & No lesions \\
\hline Kidney & No lesions & $1 / 8$ & Tubular epithelium \\
\hline
\end{tabular}

\section{DISCUSSION}

In all examined birds, the lesions in the pancreas, in the form of multifocal necrosis and hemorrhages, were the most intensive and the most frequent gross finding. This finding was confirmed by histological examination: coagulative necrosis of exocrine acinar cells was found in all samples, including the rooster $(100 \%)$. Same results were obtained in naturally infected swans in Germany (Teifke et al., 2007), while in different species of experimentally infected swans the dominant finding were pancreatic hemorrhages, and multifocal necrosis was found in a much smaller percentage (Kalthoff et al., 2008). In experimentally infected galliform birds, multifocal coagulative necrosis of pancreatic acinar cells was found in a high percentage (55-86\%) (Perkins and Swayne, 2001). These lesions were not obtained in the area of Langerhans islets, but only in exocrine cells areas, and were surrounded with mild to moderate inflammation. Lesions in the brain, including viral encephalitis, which were obtained in the examined birds, coincide with findings of other autors in naturally and experimentally infected swans (Teifke et al., 2007; Kalthoff et al., 2008) and domestic fowl (Perkins and Swayne, 2001; Nakatani et al., 2005).

Hemorrhages in the subcutaneous tissue and the sternal serosa were relatively frequent (57\% and $43 \%$ ). Theifke et al. (2007) did not observe this kind of lesion in naturally infected swans, but they were found in swans experimentally 
infected with avian influenza virus (Kalthoff et al., 2008). In the rooster, subcutaneous hemorrhages were not found, but cyanosis of the comb, bibs, and the skin of the distal parts of the legs was noticed. Similar lesions, including facial edema, hemorrhages and necrosis of pectoral muscles, were found in a high percentage (80\%) in experimentally infected domestic fowl (Perkins and Swayne, 2001).

Lung congestion and edema were found in four swans (57\%) and the rooster. Identical findings, including hemorrhages in lungs parenchyma, were reported by other autors (Perkins and Swayne, 2001; Teifke et al., 2007; Kalthoff et al., 2008).

Subepicardial hemorrhages were observed in two swans (29\%). In naturally infected swans it was a sporadic finding (Teifke et al., 2007), while in experimentally infected swans these lesions were much more frequent and pronounced (Kalthoff et al., 2008). Such lesions were not found in the rooster, although they were reported in experimentally infected galliform birds, mostly in quails and pheasants (Perkins and Swayne, 2001).

Lesions in the liver and spleen were also significant. Hemorrhages, congestion and multifocal coagulative necrosis of hepatocytes and lymphoid cells, were found in naturally infected swans and domestic fowl (Perkins and Swayne, 2001; Teifke et al., 2007; Kalthoff et al., 2008). The same findings, including a mild inflamation, were observed in four (57\%) and three $(43 \%)$ swans in our study.

In two swans, kidney swelling and congestion were macroscopically observed, while no histological lesions were found. They were not found in the kidneys of naturally and experimentally infected swans either (Teifke et al., 2007; Kalthoff et al., 2008). However, the discrete necrosis of tubular epithelial cells has been noticed in experimentally infected pheasants, quails and turkeys (Perkins and Swayne, 2001).

Hemorrhages of proventricular mucose were found in the rooster, and the same lesions were observed by other autors in experimentally infected domestic fowl (Perkins and Swayne., 2001).

Avian influenza virus was detected in all eight samples (100\%) in exocrine acinar cells of pancreas. In the same cells it was detected in a very high percentage in naturally and experimentally infected swans and domestic fowl (Perkins and Swayne, 2001; Teifke et al., 2007; Brown et al., 2008; Kalthoff et al., 2008).

Intensive immunohistochemical reaction was also detected in neurons and glial cells of the cerebrum, which is in accordance with other findings in swans and domestic fowl (Perkins and Swayne, 2001; Teifke et al., 2007; Kalthoff et al., 2008).

The viral antigen was frequently detected in the lungs (50\%), liver (62\%) and spleen (38\%), which is also very similar to findings of other autors (Perkins and Swayne, 2001; Teifke et al., 2007; Brown et al., 2008; Kalthoff et al., 2008). Viral antigen was detected in the kidney tubules in one swan (14\%), while the same finding, but in a higher percentage, was reported by other autors (Teifke et al., 2007; Kalthoff et al., 2008). It was not detected in the small intestine and the trachea, and similar results were obtained in naturally and experimentally infected 
swans, in which the virus was only detected in the trachea, in a minor percent (Teifke et al., 2007; Kalthoff et al., 2008).

Distribution of the viral antigen was in high correlation with the morphological lesions. It was most consistent in the brain and the pancreas. Having in mind the gross lesions in the pancreas, which were intensive and found in all samples, their association with the presence of the virus, and literature data (Selleck et al., 2003), it can be concluded that the pancreas is one of the most important organs for the diagnosis of avian influenza in swans. Lesions in mute swans and domestic rooster were similar in character and distribution. Established findings are very similar to the findings in swans infected with H5N1 avian influenza virus in other European countries.

Acknowledgements:

We thank Dr. Jens P. Teifke from the Federal Research Institute for Animal Health, Greifswald-Insel Riems, Germany, for providing us with avian influenza antibodies.

Address for correspondence:

Nikola Vasković, MSc, Research Associate

Veterinary Institute "Kraljevo"

Žička 34

36000 Kraljevo, Serbia

E-mail: vaskovic@vsikv.com

\section{REFERENCES}

1. Brown JD, Stallknecht $D E$, Swayne $D E$, 2008, Experimental infection of swans and geese with highly pathogenic avian influenza virus (H5N1) of asian lineage, Emerg Infect Dis, 14, 136-42.

2. Ellis TM, Bousfild RB, Bisett LA, Dyrting KC, Luk GC, Tsim ST et al., 2004, Investigation of outbreaks of highly pathogenic H5N1 avian influenza in waterfowl and wild birds in Hong Kong in late 2002, Avian Pathol, 33, 492-505.

3. Hinshaw VS, Nettles VF, Schorr LF, Wood JM, Webster RG, 1986, Influenza virus surveillance in waterfowl in Pennsylvania after the H5N2 avian outbreak, Avian Dis, 30, 207-12.

4. Kalthoff D, Breithauff A, Teifke JP, Globig A, Harder T, Mettenleiter TC et al., 2008, Highly pathogenic avian influenza virus (H5N1) in experimentally infected adult mute swans, Emerg Infect Dis 14, 1267-70.

5. Nagy A, 2007, Highly pathogenic avian influenza virus subtype H5N1 in mute swans in the Czech Republic, Vet Microbiol, 120, 9-16.

6. Nakatani H, Nakamura K, Yamamoto Y, Yamada M, Yamamoto Y, 2005, Epidemiology, pathology and immunohistochemisty of layer hens naturally affected with H5N1 highly pathogenic avian influenza in Japan, Avian Dis, 49, 436-41.

7. Perkins LE, Swayne DE, 2001, Pathobiology of A/chicken/Hong Kong/220/97 (H5N1) avian influenza virus in seven gallinaceous species, Vet Pathol, 38, 149-64.

8. Perkins LE, Swayne DE, 2002, Pathogenicity of a Hong Kong-origin H5N1 highly pathogenic avian influenza virus for emus, geese, ducks, and pigeons, Avian Dis, 46, 53-63.

9. Selleck PW, Lowther SL, Russell GM, Hooper PT, 2003, Rapid diagnosis of highly pathogenic avian influenza using pancreatic impression smears, Avian Dis, 47, 1190-5.

10. Teifke JP, Klopfleich R, Globig A, Starick E, Hoffmann B, Volf PU et al., 2007, Pathology of natural infections by H5N1 highly pathogenic avian influenza virus in mute (Cygnus olor) and whooper (Cygnus cygnus) swans, Vet Pathol, 44, 137-43. 


\title{
PATOMORFOLOŠKE PROMENE I DISTRIBUCIJA VIRUSNOG ANTIGENA KOD PTICA INFICIRANIH PATOGENIM SOJEM H5N1 VIRUSA AVIJARNE INFLUENCE
}

\author{
VASKOVIĆ N, ŠEKLER M, VIDANOVIĆ D, POLAČEK V, KUKOLJ V, MATOVIĆ K \\ i JOVANOVIĆ M
}

\begin{abstract}
SADRŽAJ
Cilj ovog ispitivanja je bio utvrđivanje patomorfoloških promena na organima ptica inficiranih H5N1 virusom avijarne influence, imunohistohemijsko utvrđivanje prisustva i distribucije virusnog antigena u parafinskim isečcima uzoraka njihovih organa, kao i utvrđivanje stepena njihove korelacije. Ispitivanje je izvršeno na organima sedam labudova grbaca (Cygnus olor) i jednog petla (Gallus gallus domesticus). Nakon izvršene obdukcije i makroskopskog pregleda svih organskih sistema, izvršeno je uzorkovanje tkiva mozga, traheje, pluća, jetre, slezine, pankreasa, bubrega i creva za patohistološka i imunohistohemijska ispitivanja. Korišćena je LSAB imunohistohemijska metoda sa poliklonskim antitelima na nukleoprotein virusa avijarne influence podtipa H5N1.

Dominantne promene utvrđene makrokopskim pregledom bile su krvavljenja i nekroze pankreasa. Histološkim pregledom su ustanovljene multifokalne nekroze pankreasa, jetre i slezine, a u velikom mozgu promene u tipu negnojnog encefalitisa, praćene distrofijom i nekrozom nervnih ćelija i pojavom neuronofagije. Virusni nukleoprotein je imunohistohemijski dokazan u pankreasu, mozgu, jetri, plućima, slezini, a kod jednog labuda i u bubrezima. Utvrđen je visok stepen korelacije između ustanovljenih patomorfoloških promena i distribucije virusnog antigena.
\end{abstract}

